\title{
Importance of Nurses' Eye Witness in Health Care System of Pakistan
}

\author{
Rashida Bibi, Dildar Muhammad, Roheeda Amanullah \\ Postgraduate Nursing College Hayatabad, Khyber Medical University, Peshawar, Khyber Pakhtunkhwa, Pakistan
}

Email address:

aalleen.zeb@gmail.com (R. Bibi), dildar.ins@kmu.edu.pk (D. Muhammad)

\section{To cite this article:}

Rashida Bibi, Dildar Muhammad, Roheeda Amanullah. Importance of Nurses' Eye Witness in Health Care System of Pakistan. Teacher Education and Curriculum Studies. Vol. 5, No. 2, 2020, pp. 38-41. doi: 10.11648/j.tecs.20200502.14

Received: August 8, 2019; Accepted: May 19, 2020; Published: June 3, 2020

\begin{abstract}
Background: Eye witness is an act that helps to provide justice, beneficence, non-maleficence and autonomy to any victim thus prevents misconduct and crimes from the society. Crime is an act of planning, preparing, stealing, harming and destroying individuals, groups or societies rights. Crime is one of the social and ethical issue that is prohibited in every religion and society. Healthcare professionals are suffering from different kind of workplace violence, harassments and abuses by patient attendants. Moreover, taking medicines or equipments from wards, and errors during surgical procedure is again consider crime. Nurses usually deal with issues and situations that have elements of ethical and moral uncertainty. Unfortunately such kind of crimes are not reported and remain unnoticed. It is our responsibility to become eye witness and report all those act which can prevent deviation from the standard of care as well as insure safety of health care providers. Methodology: Data were collected through systematic data search technique. Publication from 2001 to 2018 regarding eye witness were included in this study for review. After in depth screening, 22 articles were finally selected for review. Quality analyses were done according to pre-identified criteria. Result: Findings from retrieved and analyzed articles revealed that individuals cognitive power, confident level and theoretical knowledge is essential to become eye witness of any crime and misdeed. It is also evident from literatures that the outcome of telling lie and become fake eye witness has contextual consequences and punishment is different from context to context and person to person. According to three articles in this review, providing accurate and truth information regarding any crime is our responsibility and every religion possess and direct to provide correct information and become eye witness to prevent such acts which harm others. Conclusion: Nursing profession is facing number of challenges thus bulling and leg pulling is one of the issue which we seen in nursing profession. To take any decision and sharing any misconduct and immoral act by any person or health care providers we must have enough knowledge, confident, cognitive integrity to identify our personal values, moral development and knowledge of ethical theories for decision making in nursing to be a eye witness or not.
\end{abstract}

Keywords: Witness, Nursing Practice, Challenges, Deception, Culprit, Victim

\section{Introduction}

Ethical decision making is difficult process as it needs thorough theoretical knowledge of ethical principle. [1, 2] Eye witness is an moral act which can helps to provide justice, beneficence, non-maleficence and autonomy to individual, groups and societies. [3] Different approaches are carrying out to provide justice for a victim or society as a whole, and eye testimony is one convenient approach for jury to provide justice in all judiciary system. [4] Eye witness some time becomes dilemma because of various factors. Evidence shows that approximately $71 \%$ eye witnesses were wrong assurance after DNA test of some criminal cases. [5] Eye witness some time becomes dilemma because of various factors. Evidence shows that approximately $71 \%$ eye witnesses were wrong assurance after DNA test of some criminal cases $[5,6]$. Enough information are needed to provide justice for some oppressors and victims. We can be act as a eye witness to provide social justice and minimize criminal acts from society. Crime has systematic effects on fundamental human rights of any population across the world. [3, 7]

\subsection{Importance of Eye Witness in formal investigations}

Eye witness to a crime is a part of an objective 
investigation that is critical process, so it is not easy to become eye witness and involve in investigation process, therefore, we don't prefer to become eye witness for any misdeed and ultimately suppressed our thoughts. It is evident from literature that that the eye witness is not a complete way and accurate accounts of any wrong act even when is it judge to be completely factual. $[8,9]$ The rationalist theory of ethic support this to not be eye witness in a sense of everyone has their own perception of situation. [10, 11] It is one of the actions which produce conflict, break confidentiality, violation of human dignity and sometime leads to take wrong decision, thread of any physical harm, dealing for robbery, and some time eye witness receive physical, mental and social threads from criminal actors. [8, 12] Eye witness may misinterpret the actual situation which is against our ethical values. [12] Studies shows that human brain is not perfectly memorize all the pictures of scenario, sometime our witness goes to opposite and charge some innocent as offender so injustice may arise. [13] Visit to a concern department in multiple times and every time his or her description about crime has been recorded which have tendency to change in our sentence and sometime becomes social and cultural issue for females.

Crime is unethical, immoral, against of human rights and unacceptable for any one in a society. [2, 14] Crime is any kind of misdeed which violate others rights and may harm physically, socially and economically. Making decision to become eye witness is depend on individual confident and knowledge of ethical principles that is; beneficence, nonmaleficence, veracity and fidelity. Information must be provided freely and voluntarily without compelling influence. $[4,6]$ Truth telling is necessary when the expected outcome is beneficent for the majority. We can save right of someone if we provide enough information for justice to oppressors, Thus eye witness is one of the key for justice and preventive strategy for criminal acts. Ethical decision making is difficult process for individual which need thorough knowledge of ethical principles and theoretical knowledge to take decision. Eye witness is an act to provide justice, beneficent, nonmaleficent and autonomy. [15] Different approaches are carrying out to provide justice for a victim or society as a whole, and eye testimony is one convenient approach for jury to provide justice in all judiciary system. [12] Eye witness has an important value in Islamic judiciary system from the time of out Holy Prophet (S.AW) the judiciary system was well structured in which justice were provided only based on eye witness. The Utilitarianism theory supported to take decision on the basis of its outcome, happiness and benefits for the majority, therefore concealing eye witness is one of the big sins. [16] In Surah Nisa Allah said ''Do not conceal testimony, and whoever conceals it, his heart is surely sinful; and Allah knows what you do. 'Keeping in secret all about eye witness is a sin of the heart, and sole. [17] When a person concealed any reality in his heart remain in stress and unsatisfied. In present collecting evidence from eye witness has still pronoun contribution to provide justice and give punishment to offenders. Throughout the history, agreement on eye witness has significance to make accurate decision against criminal acts. Infect eye witness is never taken to be absolute fact but it paves the way to minimize criminal activities in a society or in an organization and victim get justice some time by your few truthful sentence. And the witness should not refuse when they are summoned. [16] To keep strong faith on personal values and moral development as well as ethical theoretical guidance it is our obligation to not conceal any crime and unethical act to those who responsible to provide justice and maximize the happiness and beneficent. Allah said in Surah an-Nisa " if you trust and certain than maintain justice and bearer of witness for Allah sake only. [17] Though it may be against your near and dears, rich or poor. Allah said that do not follow your own desire less you deviate surely.

\subsection{Cod of Ethic/Principals of Eye Witness}

The eye witness must be certain and not mentioned such things which he himself not heard. Deontological point of view allows us to strictly follow the professional code of ethic and individual right. If someone punished due to our own interpretative testimony than we do injustice with him or her and person remain in thread of that person to take revenge. [1] One must not feel undue compassion for the accused who is poor. If there is no chance to harm anyone than no need to be eye witness and can remain silent. Memory is known to be limited and imperfect in number of ways. [11] Memory may be interfered by external threads, personal biased, your physical and mental ability and passage of time are some factors due to which we must not be declare our self as eye witness of any crime. [12, 18]

It is universally agreement that any negative act of human, need to be punished after evaluating the intensity of a crime. In Islam, to become eye witness is a primary obligation to provide justice, and the foundation of Islam is based on justice and morality. According to [19] report every wrong act is a legal device which ensures the rights of victims. Allah said in the Holy Quran that ' and who is more unjust than he who conceals a testimony that he has from Allah. [16] Our cod of ethic is based on deontological theory which emphasize to be honest in our duty and if someone doing wrong, we have to take decision according to ethical principles and based on ethical theories. become eye witness as a nurse we must possess sufficient knowledge of ethical principles and theoretical information's any type of crime which has some negative impact on others must be notify so eye witness is one act which must be follow by individual to provide justice and enhance beneficent and veracity. By keeping faith on Allah it is our obligation to not follow our low desires and personal interest than surely Allah ask us one day and $\mathrm{He}$ is aware what we concealed. Thus one must not conceal testimony due to the fear of the rich or mercy for the poor. In other hand empirical science support that the human brain is a sufficient and accurate recorder of events that testimony constituting subjective reports of the contents of memory is universally admitted and considered as evidence. $[15,20]$ Witness testimony must consider the veracity of the 
witness. One should neither pay heed to one's own interest nor care for any other person while giving testimony. Nursing related felonies, we see very frequently in our practice. Stealing medicines, medical negligence and taking things from patients is common mini crime which notice in any health care institution.

\section{Methodology}

Search engines were used to find out literature. Four data base were selected to find out articles related to the important of the eye witness in nursing profession including all other situation. Data base were selected for search includes: Google scholar, Pub Med, Springer, Science Hub, MEDLINE and Google search engine. Google and Wikipedia were approached and selected some important variables to conducted vast literature searches. After selecting various key words, I combined and refined the key words used in first searched with MESH terms. Used the Boolean terms as AND OR than group of some key words merge together with MESH transitional words. Total of 277 literature were found related to eye witness. All the titles, abstracts and conclusion were screened and evaluated to exclude all duplicated and out dated articles. Total 25 articles were assessed to meet the inclusion criteria of further review. After in depth screening of the 20 articles were finally selected for review.

\section{Discussion}

Eye testimony is one of the subjective report of our memory and it is fact that human memory is one source to give direction and help to investigate some unethical issue but some time our brain may interpret the situation in different way. [5] Majority of the researcher identified that, all acts that violate and harm individual right and create injustice are crimes. $[2,21,22]$ but we need to take decision to become eye witness depends upon our values, person dignity, outcome of our action as eye witness about the seen crime. Sometime the situation does not permit us to be committed for eye witness instead of knowing all about injustice acts. [18] In such condition our inner self decide to ignore the situation purposefully. Some factors which not allowed revealing the fact are class differences, gender discrimination, robbery etc. which consequently suppress justice and veracity.

There may be occasion when a person has not directly witnessed a transaction but has some information for having heard or seen something related to the issue. If the information he has can save a person from harm or enable him to secure his right or benefit for them, it become our obligation on this person to testify, if he asks for evidence. If by not disclosing what he knows, a Muslim is harmed or lost his right, it is become a big sin to remain silent. [21] In short if a person is capable of helping the oppressed or prevent the oppressor from oppressing than you must be contribute to provide accurate information. According to [3] if your witness minimizes injustice and criminal acts than it is your obligation to do so. It should be known that a testimony should not endanger the life, property or honor of a Muslim. [16] It should also not pose a threat to the life, property and honor of the witness. It is obligatory to give evidence and it is sin to conceal it so, justice is established in the society and injustice is eradicated. The oppressor ought to be punished and the right may be restored to its owner but if the testimony itself becomes the cause of oppression than it is not obligatory to testify. The psychological impact of workplace violence is not only an issue for the victim but also for any co-workers that witnessed the incident or for co-workers that hear about the incident after it happened. In some severe cases, a healthcare worker may go into crisis as the result of being a workplace violence victim or witness. To become eye witness for any crime is still challenging for every one because of its consequences but one whose possesses some evidence has to make it known and when he is ask for it than he must give it or he must fulfill his or her obligation without any fear of other criticism. Justice should be our priority so acting in equitable way and careful that Allah is aware all of what you do. Veracity is one of the ethical and moral obligation so no feeling of amenity to come in a way of truth telling. [2] It is our duty to give the evidence of that unethical acts. This is not a valid excuse for withholding evidence as [4] support that offender must be punished according to policy even if the witness has suffered and loss. Hence we concluded that false oath, and concealing evidence, each of these are greater sins if there is no risk of any harm to our life. Sometime our action become compulsory to save some one right and provide justice, however as far as possible one must give priority to the more important alternative.

\section{Conclusion}

Honesty, accountability and competency is required to become eye witness of any crime. Eye witness is one of the basic element that aids in distinguishing culprits and victims. It is our obligation to provide correct information to authorities and decision makers for taking necessary measures against criminal acts. Nurses are front line health care workers thus they need to be very confident and have comprehensive information before providing information and become eye witness to save the life of others. Hospital administration must provide work autonomy and empower nurses to take independent decision and become eye witness of any misconduct in hospital.

\section{References}

[1] Lorenza SM. Factors Affecting the Accuracy of Eyewitness Identification. 2003; 6: 45-50.

[2] Beauchamp, T. \& CJ. principles of biomedical ethics. 6th ed. Oxford university press New york; 2009. 9-18 p.

[3] Charter T, Rights P. Crimes against humanity. 2010; 7 (2): 1-3. 
[4] Mckay R, Whitehouse H. Religion and Morality. 2015; 141 (2): 447-73.

[5] Farwell LA. Brain fingerprinting: a comprehensive tutorial review of detection of concealed information with eventrelated brain potentials. $2012.115-154 \mathrm{p}$.

[6] Lindholm T. Who can judge the accuracy of eyewitness statements? A comparison of professionals and lay-persons. Appl Cognit Psychol. 2008 Dec; 22 (9): 1301-14.

[7] Wixted JT, Wells GL. The Relationship Between Eyewitness Confidence and Identification Accuracy: A New Synthesis. Psychol Sci Public Interest. 2017 May; 18 (1): 10-65.

[8] Enfermagem RL, Carine A, Rolim A, Maria S, Gondim M, Paz S. Factors associated with reporting of abuse against children and adolescents by nurses within Primary Health Care 1. 2014; 22 (6): 1048-55.

[9] Yonas MA, Burke JG, Brown ST, Jeffrey D, Garland R, Burke DS, et al. NIH Public Access. 2014; 40 (1 0): 1-20.

[10] J. J. c S. Utilitarianism. 4rth ed. Williums. B, editor. Combridge university press; $1997.110-123 \mathrm{p}$.

[11] Vrij A, Fisher RP, Blank H. A cognitive approach to lie detection: A meta-analysis. Leg Crim Psychol. 2017 Feb; 22 (1): $1-21$.

[12] Son LK, editor. Bridging cognitive science and ecucation: learning, memory, and metacognition. Hove: Psychology Press; 2007. 481 p. (The journal of cognitive psychology Special issue).

[13] Fisher RP, Brewer N, Mitchell G. Handbook of Psychology of Investigative Interviewing: Current Developments and Future Directions.: 1-15.
[14] Lindsay DS, Read JD, Sharma K. Accuracy and Confidence in Person Identification: The Relationship Is Strong When Witnessing Conditions Vary Widely. Psychol Sci. 1998 May; 9 (3): 215-8.

[15] Mansour JK, Beaudry JL, Lindsay RCL. Are multiple-trial experiments appropriate for eyewitness identification studies? Accuracy, choosing, and confidence across trials. Behav Res. 2017 Dec; 49 (6): 2235-54.

[16] Essay on The Origins and Importance of the Quran - 1128 Words | Bartleby [Internet]. [cited 2020 May 18]. Available from: https://www.bartleby.com/essay/The-Origins-andImportance-of-the-Quran-P3CUUFRZTJ

[17] Surah An-Nisa [4:24] - Al-Qur'an al-Kareem [Internet]. [cited 2020 May 18]. Available from: https://quran.com/4/24.

[18] Lindholm T. Group-Based Biases and Validity in Eyewitness Credibility Judgments: Examining Effects of Witness Ethnicity and Presentation Modality 1. J Appl Social Pyschol. $2005 \mathrm{Jul} ; 35$ (7): 1474-501.

[19] Vrij A. Deception and truth detection when analyzing nonverbal and verbal cues. Appl Cognit Psychol. 2019 Mar; 33 (2): 160-7.

[20] Mansour JK, Beaudry JL, Bertrand MI, Kalmet N, Melsom EI, Lindsay RCL. Impact of disguise on identification decisions and confidence with simultaneous and sequential lineups. Law and Human Behavior. 2012; 36 (6): 513-26.

[21] Bartlett. Ethics Surrounding Interviewing. Jones; 19-34 p.

[22] Connor JA, Ziniel SI, Porter C, Doherty D, Moonan M, Dwyer $\mathrm{P}$, et al. Interprofessional Use and Validation of the AACN Healthy Work Environment Assessment Tool. Am J Crit Care. 2018 Sep; 27 (5): 363-71. 